\title{
Antioxidant and Anticholinesterase Activities of Essential Oil of Alseodaphne peduncularis Meisn
}

\author{
Alseodaphne peduncularis Meisn. Uçucu Yağının Antioksidan ve Antikolinesteraz \\ Aktivitesi
}

Wan Mohd Nuzul Hakimi Wan SALLEH, Farediah AHMAD*

Department of Chemistry, Faculty of Science, Universiti Teknologi Malaysia, 81310 Johor Bahru, Johor, MALAYSIA

\begin{abstract}
This study was designed to investigate the antioxidant and anticholinesterase activities of the essential oils from Alseodaphne peduncularis Meisn. GC and GC/MS analysis of the leaves oil showed thirty one components representing $72.6 \%$ of the oil. The most abundant components were $\beta$-caryophyllene (24.0\%), $\delta$-cadinene (15.9\%) and germacrene B (12.2\%). The antioxidant activity was determined by DPPH (1,1-diphenyl2-picrylhydrazyl) radical scavenging and total phenolic content assays, while anticholinesterase activity assessed by measuring inhibition of acetylcholinesterase (AChE) and butyrylcholinesterase (BChE) enzymes. The essential oil showed weak activity in the DPPH radical scavenging $\left(\mathrm{I} \mathrm{C}_{50}\right.$ of $253.2 \mu \mathrm{g} / \mathrm{mL}$ ) and phenolic content $(32.5 \mathrm{mg} \mathrm{GA} / \mathrm{g})$, while moderate inhibition activity against AChE (I: 45.2\%) and BChE (I: 48.6\%).

Key words: Essential oil, Alseodaphne peduncularis, Antioxidant activity, Anticholinesterase activity, Lauraceae
\end{abstract}

\section{ÖZ}

Bu çalıșma Alseodaphne peduncularis Meisn. uçucu yağının antioksidan ve antikolinesteraz aktivitelerini araştırmak için tasarlanmıştır. GC ve GC/MS analizleri yaprak yağında \%72,6 oranında otuz bir bileșen bulunduğunu göstermiştir. En çok bulunan bileșenler $\beta$-karyofilen (\%24,0), $\delta$-kadinen $(15,9)$ ve germakren B $(\% 12,2)$ dir. Antioksidan aktivite DPPH (1,1- difenil-2-pikrilhidrazil) radikal süpürme ve toplam fenolik içerik yöntemleriyle değerlendirilirken, antikolinesteraz aktivite asetilkolinesteraz (AChE) ve bütirilkolinesteraz (BChE) enzim inhibisyonu ölçülerek değerlendirilmiştir. Uçucu yağ, zayıf DPPH radikal süpürme aktivitesi (IC 50 değeri 253,2 mg/mL) ve fenolik içerik (32,5 mg GA/g) gösterirken, AChE (I: \%45,2) ve BChE (I: \%48,6) inhibisyon aktivitesi orta düzeydedir.

Anahtar kelimeler: Uçucu yağ, Alseodaphne peduncularis, Antioksidan aktivite, Antikolinesteraz aktivite, Lauraceae

\section{INTRODUCTION}

Alseodaphne is a genus of small to medium sized trees of the wet evergreen tropical forests. The genus is having more than fifty species and distributed in tropical belt of Cambodia, China, Indonesia, Laos, Malaysia, Myanmar, Philippines, Sri Lanka, Thailand, Vietnam and India. There is no information in the literature regarding medicinal uses of genus Alseodpahne. Most of the species of genus are unexplored, both, pharmacologically and phytochemically (1). Previous phytochemical investigations of Alseodaphne have resulted in the isolation of alkaloids (aporphines, bisbenzylisoquinoline, morphinandienones) (2), lactones (3), neolignans (4) and phenanthrenes (5). The isolated constituents of genus Alseodaphne might become useful as a source of pharmacologically interesting molecules.
A. peduncularis is a shrub or sometimes a small tree of up to 6-12 m height. The twigs colour is whitish. The leaves/ stalk is slender and around $0.51 \mathrm{~cm}$ long in size. The blade is membranous and lanceolate with drying greenish brown colour. The midrib rise above and secondary nerves is about 610 pairs, curving and joining near margin and rise on both surfaces. The tertiary nerves are reticulate and visible on both the surfaces. The colour of the flowers is greenish. The shape of fruits is ellipsoid or globose with a dark purple colour and on enlarged red perianth tube (1).

To the best of our knowledge there is no report on the chemical compositions of the essential oil of $A$. peduncularis, therefore we would like to report their chemical composition and their antioxidant and anticholinesterase activities. 


\section{MATERIALS AND METHODS}

\section{Plant materials}

A sample of $A$. peduncularis was collected from Hutan Simpan Bangi, Selangor in September 2015, and identified by Dr. Shamsul Khamis from Institute of Biosience (IBS), Universiti Putra Malaysia (UPM). The voucher specimen (SK2955/16) were deposited at the Herbarium of IBS, UPM.

\section{Solvents and chemicals}

Antioxidant: 1,1-Diphenyl-2-picrylhydrazyl (DPPH), gallic acid and butylatedhydroxytoluene (BHT) were obtained from Sigma-Aldrich (Germany). Analytical grade methanol, ethanol and dimethylsulfoxide (DMSO), HPLC grade chloroform, Folin-Ciocalteu's reagent, anhydrous sodium sulphate, and sodium carbonate were purchased from Merck (Germany). Anticholinesterase: AChE enzyme (Type-VI-S, EC3.1.1.7), butyrylcholinesterase enzyme (BChE; EC3.1.1.8), acetylthiocholine iodide, butyrylthiocholine chloride, 5,5'-dithio-bis(2-nitrobenzoic)acid (DTNB), and galantamine were purchased from Sigma-Aldrich (Germany).

\section{Extraction of essential oils}

The fresh leaf ( $300 \mathrm{~g}$ ) was subjected to hydrodistillation in an all glass Dean-stark apparatus for 6 hours. The oils obtained were dried over anhydrous magnesium sulfate and stored at $4-6^{\circ} \mathrm{C}$. The oil yield $(\mathrm{w} / \mathrm{w})$ was $1.55 \mathrm{~g}(0.52 \%)$ based on the fresh weight.

\section{Gas chromatography (GC)}

GC analysis were performed on a Hewlett Packard 6890 series II A gas chromatograph equipped with an Ultra-1 column (100\% polymethylsiloxanes) (25 m long, $0.33 \mu \mathrm{m}$ thickness and $0.20 \mathrm{~mm}$ inner diameter). Helium was used as a carrier gas at flow rate of $0.7 \mathrm{~mL} / \mathrm{min}$. Injector and detector temperature were set at 250 and $280^{\circ} \mathrm{C}$, respectively. Oven temperature was kept at $50^{\circ} \mathrm{C}$, then gradually raised to $280^{\circ} \mathrm{C}$ at $5^{\circ} \mathrm{C} / \mathrm{min}$ and finally held isothermally for $15 \mathrm{~min}$. Diluted samples (1/100 in diethyl ether, $v / v)$ of $1.0 \mu \mathrm{L}$ were injected manually (split ratio 50:1). The injection was repeated three times and the peak area percents were reported as means $\pm \mathrm{SD}$ of triplicates. Calculation of peak area percentage was carried out by using the GC HP Chemstation software (Agilent Technologies).

\section{Gas chromatography-mass spectrometry (GC-MS)}

GC-MS chromatograms were recorded using a Hewlett Packard Model 5890A gas chromatography and a Hewlett Packard Model 5989A mass spectrometer. The GC was equipped with Ultra-1 column ( $25 \mathrm{~m}$ long, $0.33 \mu \mathrm{m}$ thickness and $0.20 \mathrm{~mm}$ inner diameter). Helium was used as a carrier gas at a flow rate of $1 \mathrm{~mL} / \mathrm{min}$. Injector temperature was $250^{\circ} \mathrm{C}$. Oven temperature was programmed from $50^{\circ} \mathrm{C}(5 \mathrm{~min}$ hold) at $10^{\circ} \mathrm{C} / \mathrm{min}$ to $250^{\circ} \mathrm{C}$ and finally held isothermally for 15 min. For GC-MS detection, an electron ionization system, with ionization energy of $70 \mathrm{eV}$ was used. A scan rate of 0.5 s (cycle time: $0.2 \mathrm{~s}$ ) was applied, covering a mass range from 50-400 amu.

\section{Identification of components}

The constituents of the oil were identified by comparison of their mass spectra with reference spectra in the computer library (Wiley) and also by comparing their retention indices, with data in the literature (6). The quantitative data were obtained electronically from FID area percentage without the use of correction factor.

\section{Antioxidant activity}

\section{DPPH radical scavenging}

The free radical scavenging activity was measured by the DPPH method with minor modifications (7). Each sample of stock solution $(1.0 \mathrm{mg} / \mathrm{mL})$ was diluted to final concentration of $1000-7.8 \mu \mathrm{g} / \mathrm{mL}$. Then, a total of $3.8 \mathrm{~mL}$ of $50 \mu \mathrm{M} \mathrm{DPPH}$ methanolic solution $(1 \mathrm{mg} / 50 \mathrm{~mL}$ ) was added to $0.2 \mathrm{~mL}$ of each sample solution and allowed to react at room temperature for $30 \mathrm{~min}$. The absorbance of the mixtures was measured at $517 \mathrm{~nm}$. A control was prepared without sample or standard and measured immediately at 0 min. Lower absorbance of the reaction mixture indicates higher free radical scavenging activity, and vice versa. The percent inhibitions (I\%) of DPPH radical were calculated as follow:

$1 \%=[$ Ablank - Asample $/$ Ablank $] \times 100$

where Ablank is the absorbance value of the control reaction and Asample is the absorbance values of the test samples. The sample concentration providing $50 \%$ inhibition ( $\mathrm{IC}_{50}$ ) was calculated by plotting inhibition percentages against concentrations of the sample. All tests were carried out in triplicate and $\mathrm{IC}_{50}$ values were reported as means $\pm \mathrm{SD}$ of triplicates.

\section{Total phenolic content (TPC)}

Total phenolic contents of the essential oils were determined as described previously (8). A sample of stock solution (1.0 $\mathrm{mg} / \mathrm{mL}$ ) was diluted in methanol to final concentrations of $1000 \mu \mathrm{g} / \mathrm{mL}$. A $0.1 \mathrm{~mL}$ aliquot of samplewas pipetted into a test tube containing $0.9 \mathrm{~mL}$ of methanol, then $0.05 \mathrm{~mL}$ FolinCiocalteu's reagent was added, and the flask was thoroughly shaken. After $3 \mathrm{~min}, 0.5 \mathrm{~mL}$ of $5 \% \mathrm{Na}_{2} \mathrm{CO}_{3}$ solution was added and the mixture was allowed to stand for $2 \mathrm{~h}$ with intermittent shaking. Then, $2.5 \mathrm{~mL}$ of methanol was added and left to stand in the dark for $1 \mathrm{~h}$. The absorbance measurements were recorded at $765 \mathrm{~nm}$. The same procedure was repeated for the standard gallic acid solutions. The concentration of total phenolic compounds in the oils was expressed as mg of gallic acid equivalent per gram of sample. Tests were carried out in triplicate and the gallic acid equivalent value was reported as mean \pm SD of triplicate.

\section{Anticholinesterase activity}

AChE/BChE inhibitory activity of the essential oils was measured by slightly modifying the spectrophotometric 
Table 1. Constituents identified from the essential oil of A. peduncularis

\begin{tabular}{|c|c|c|c|}
\hline No & Components & $\mathrm{KI}^{\mathrm{a}}$ & Percentage (\%) \\
\hline 1 & $\delta$-Elemene & 1335 & 1.5 \\
\hline 2 & $\alpha$-Cubebene & 1345 & 0.5 \\
\hline 3 & $\alpha$-Ylangene & 1373 & 0.1 \\
\hline 4 & $\alpha$-Copaene & 1374 & 2.5 \\
\hline 5 & $\beta$-Copaene & 1374 & 0.8 \\
\hline 6 & Isoledene & 1375 & 0.3 \\
\hline 7 & $\beta$-Cubebene & 1387 & 0.4 \\
\hline 8 & $\alpha$-cis-Bergamotene & 1411 & 0.4 \\
\hline 9 & $\beta$-Caryophyllene & 1417 & 24.0 \\
\hline 10 & $\alpha$-trans-Bergamotene & 1432 & 0.1 \\
\hline 11 & $\gamma$-Elemene & 1434 & 5.2 \\
\hline 12 & $\alpha$-Guaiene & 1437 & 0.0 \\
\hline 13 & 6,9-Guaiadiene & 1442 & 0.6 \\
\hline 14 & cis-Cadina-1(6)4-diene & 1461 & 0.2 \\
\hline 15 & trans-Cadina-1(6)4-diene & 1475 & 0.4 \\
\hline 16 & $\gamma$-Muurolene & 1478 & 0.9 \\
\hline 17 & $\beta$-Selinene & 1489 & 0.6 \\
\hline 18 & $\beta$-Guaiene & 1492 & 0.1 \\
\hline 19 & $\gamma$-Amorphene & 1495 & 0.3 \\
\hline 20 & Valencene & 1496 & 0.3 \\
\hline 21 & Cubebol & 1514 & 0.3 \\
\hline 22 & $\delta$-Cadinene & 1522 & 15.9 \\
\hline 23 & $\alpha$-Cadinene & 1537 & 0.1 \\
\hline 24 & $\gamma$-Cadinene & 1543 & 0.2 \\
\hline 25 & Germacrene B & 1559 & 12.2 \\
\hline 26 & (E)-Nerolidol & 1561 & 0.1 \\
\hline 27 & Spathulenol & 1577 & 0.2 \\
\hline 28 & Caryophyllene oxide & 1582 & 0.8 \\
\hline 29 & Globulol & 1590 & 0.2 \\
\hline 30 & Epicubenol & 1627 & 1.0 \\
\hline 31 & trans-Longipinocarveol & 1634 & 0.2 \\
\hline 32 & t-Muurolol & 1644 & 1.9 \\
\hline 33 & $\beta$-Eudesmol & 1649 & 0.1 \\
\hline 34 & $\alpha$-Bisabolol & 1685 & 0.1 \\
\hline 35 & Phytol & 1942 & 0.1 \\
\hline
\end{tabular}

Group components

\begin{tabular}{cl}
\hline \multicolumn{1}{c}{ Sesquiterpene hydrocarbons } & 67.6 \\
\hline Oxygenated sesquiterpenes & 5.0 \\
\hline Identified components (\%) & 72.6 \\
\hline
\end{tabular}

aKovat's indices (KI) experimental: $\mathrm{n}$-alkanes $\left(\mathrm{C}_{9}-\mathrm{C}_{30}\right)$ were used as reference points in the calculation of KI method developed by Ellman et al. (9) and Orhan et al. (10). Electric eel (Electrophorus electricus) AChE and horse serum BChE were used, while acetylthiocholine iodide (AChl) and butyrylthiocholine chloride (BChl) were employed as substrates of the reaction. DTNB acid was used for the measurement of the anticholinesterase activity. Briefly, in this method, $140 \mu \mathrm{L}$ of sodium phosphate buffer ( $\mathrm{pH} 8.0$ ), $20 \mu \mathrm{L}$ of DTNB, $20 \mu \mathrm{L}$ of essential oils and $20 \mu \mathrm{L}$ of AChE/ $\mathrm{BChE}$ solution were added by multichannel automatic pipette in a 96-well microplate and incubated for $15 \mathrm{~min}$ at $25^{\circ} \mathrm{C}$. The reaction was then initiated with the addition of $10 \mu \mathrm{L}$ of AChl/BChl. Hydrolysis of AChl/BChl was monitored by the formation of the yellow 5-thio-2-nitrobenzoate anion as a result of the reaction of DTNB with thiocholines, catalyzed by enzymes at $412 \mathrm{~nm}$ utilizing a 96-well microplate reader (Epoch Micro-Volume Spectrophotometer). Percentage inhibition (I\%) of AChE/BChE was determined by comparison of rates of reaction of samples relative to blank sample $(\mathrm{EtOH}$ in phosphate buffer $\mathrm{pH} 8$ ) using the formula:

$1 \%=[\mathrm{E}-\mathrm{S} / \mathrm{E}] \times 100$

where $E$ is the activity of enzyme without test sample and Sis the activity of enzyme with test sample. The experiments were done in triplicate. Galantamine was used as reference.

\section{Statistical analysis}

Data obtained from essential oil analysis and their bioactivities were expressed as mean values. The statistical analyses were carried out by employing one way ANOVA ( $p<0.05$ ). A statistical package (SPSS version 11.0) was used for the data analysis.

\section{RESULTS AND DISCUSSION}

Hydrodistillation of the fresh leaves of $A$. peduncularis gave pale yellow oil in $0.52 \%(\mathrm{w} / \mathrm{w})$. The chemical compositions of the leaves oil of $A$. peduncularis are listed in Table 1. GC and GC-MS analysis of the essential oil had successfully found thirty five components, which accounted for $72.6 \%$ of the chromatographical components. Sesquiterpene hydrocarbons were the major components in the essential oil (67.6\%) with $\beta$-caryophyllene (24.0\%) being the most substantial component, followed by $\delta$-cadinene $(15.9 \%)$ and germacrene B (12.2\%). Furthermore, oxygenated sesquiterpenes made

\section{Table 2. Antioxidant and anticholinesterase activities of the} essential oil of $A$. peduncularis

\begin{tabular}{|c|c|c|c|c|}
\hline Samples & $\begin{array}{l}\text { DPPH IC } \\
(\mu \mathrm{g} / \mathrm{mL})^{\mathrm{a}}\end{array}$ & $\begin{array}{l}\text { TPC } \\
(\mathrm{mg} \mathrm{GA} / \mathrm{g})^{\mathrm{b}}\end{array}$ & AChE (I\%)c & $\begin{array}{l}\text { BChE } \\
(1 \%)^{c}\end{array}$ \\
\hline Essential oil & 253.2 & $32.5 \pm 0.1$ & $45.2 \pm 0.2$ & $48.6 \pm 0.2$ \\
\hline $\mathrm{BHT}$ & 18.5 & - & - & - \\
\hline Galantamine & - & - & $95.9 \pm 0.2$ & $88.7 \pm 0.2$ \\
\hline
\end{tabular}


up a minor fraction which gave $5.0 \%$, while monoterpenoids were not found in this essential oil.

The antioxidant activities were investigated by DPPH free radical scavenging assay together with the Folin-Ciocalteu assay which evaluated the total phenolic content of the essential oil. The results are displayed in Table 2 . The antioxidant activity on DPPH radical scavenging is due to their hydrogen donating ability. The capability of substances to donate hydrogen is able to convert DPPH into their non-radical form DPPH and the reaction can be followed spectrophotometrically (11). The essential oil exhibited weak $\mathrm{DPPH}$ radical scavenging activity $\left(\mathrm{IC}_{50}\right.$ of $253.2 \mu \mathrm{g} / \mathrm{mL}$ ) compared to standard antioxidant, BHT ( $\mathrm{IC}_{50}$ of $18.5 \mu \mathrm{g} / \mathrm{mL}$ ). The low activity was attributed to the low phenolic content of the essential oil which is responsible for antioxidant activity. This was supported by the results of the Folin-Ciocalteu assay on the essential oils, which showed low amount of phenolic (32.5\%). AChE plays an important role in the central nervous system. It is one of the fastest known enzymes and catalyses the cleavage of acetylcholine in the synaptic cleft after depolarisation. Inhibitors of AChE, such as galanthamine, are used frequently in the pharmacotherapy of Alzheimer disease (12). The essential oil indicated moderate AChE and BChE activity at $1000 \mu \mathrm{g} / \mathrm{mL}$ concentration, which gave $45.2 \%$ and $48.6 \%$ for AChE and BChE activity, respectively. In previous reports, $A C h E$ inhibition can be explained by the high content of monoterpenes. It has been mentioned that 1,8-cineole, camphor, $\alpha$-pinene, $\beta$-pinene, borneol, linalool, menthone, carvone, anetole, anisole, have anticholinesterase eactivity (13-15). This current oil lacked the presence of monoterpenes, hence contributed to the low AChE/BChE inhibition.

\section{CONCLUSION}

In conclusion, essential oil and their components generally displayed significant bioactivity properties, which are useful as preventive agents from various diseases. In the case of A. peduncularis oil, although there is no striking on their bioactivity in the oil, it is still worthwhile to investigate the other parts of the plant as a natural source for essential oil composition or their phytochemical studies.

\section{ACKNOWLEDGMENTS}

The authors thank the Ministry of Science, Technology and Innovation Malaysia for financial support under vote
QJ130000.2526.03H93 and the Faculty of Science, Universiti Teknologi Malaysia for research facilities.

\section{REFERENCES}

1. Bandana KT, Amit A, Devendra SR, Bipin R, Rashmi, Rawat MSM. A review on genus Alseodaphne: Phytochemistry and pharmacology. Mini-Rev Org Chem 9, 433-445, 2012

2. Nafiah MA, Mukhtar MR, Morita H, Ahmad K, Awang K, Hadi AHA. Alkaloids from roots of Alseodaphne corneri Kosterm. Malays J Sci 29, 281-284, 2010.

3. Lee SS, Chang $\mathrm{SM}$, Chen $\mathrm{CH}$. Chemical constituents from Alseodaphne andersonii. J Nat Prod 64, 1548-1551, 2001.

4. Chang $\mathrm{H}$, Liu L, Tu P. Chemical constituents of Alseodaphne hainanensis. Zhongcaoyao 31, 725-727, 2000.

5. Mahmud Z, Khan MN, Lajis NH, Toia RF. Perakensol: Aphenanthrenoid isolated from Alseodaphne perakensis. J Nat Prod 55, 533-535, 1992.

6. Adams RP. Identification of essential oil by gas chromatographyquadrupole/mass spectroscopy. Allured Publishing Corporation, Carol, Stream IL, USA, 2001.

7. Salleh WMNHW, Ahmad F, Khong HY, Zulkifli RM. Chemical compositions and biological activities of essential oils of Beilschmiedia glabra. Nat Prod Commun 10, 1297-1300, 2015.

8. Salleh WMNHW, Ahmad F, Khong HY. Antioxidant and anticholinesterase activities of essential oils of Cinnamomum griffithii and C. macrocarpum. Nat Prod Commun 10, 1465-1468, 2015.

9. Ellman GL, Courtney KD, Andres V, Feather-Stone RM. A new and rapid colorimetric determination of acetylcholinesterase activity. Biochem Pharmacol 7, 88-95, 1961.

10. Orhan I, Aslan S, Kartal M, Sener B, Baser KHC. Inhibitory effect of Turkish Rosmarinus officinalis $L$. on acetylcholinesterase and butyrylcholinesterase enzymes. Food Chem 108, 663-668, 2008.

11. Soares JR, Dinis TCP, Cunha AP, Almeida LM. Antioxidant activity of some extracts of Thymus zygis. Free Radic Res 26, 469-478, 1997.

12. Loizzo MR, Menichini F, Conforti F, Tundis R, Bonesi M, Saab AM, Statti GA, de Cindio B, Houghton PJ, Menichini F, Frega NG. Chemical analysis, antioxidant, antiinflammatory and anticholinesterase activities of Origanum ehrenbergii Boiss and Origanum syriacum L. essential oils. Food Chem 117, 174-180, 2009.

13. Savelev S, Okello E, Perry NS, Wilkins RM, Perry EK. Synergistic and antagonistic interactions of anticholinesterase terpenoids in Salvia lavandulaefolia essential oil. Pharmacol Biochem Behav 75, 661-668, 2003.

14. Sajjadi SE, Shahpiri Z. Chemical composition of the essential oil of Salvia limbata C.A. Mey. Daru J Pharm Sci 12, 94-97, 2004.

15. Picollo MI, Toloza AC, Mougabure CG, Zygadlo J, Zerba E. Anticholinesterase and pediculicidal activities of monoterpenoids. Fitoterapia 79, 271-278, 2008. 